\title{
A PESSOA COM DEFICIÊNCIA FÍSICA E O MERCADO DE TRABALHO: ESTUDO EMPÍRICO NO MUNICÍPIO DE TANGARÁ DA SERRA-MT, DOS AFILIADOS DA ASTANDEF E EMPRESAS INSERIDAS NO REGIME DE COTAS CONFORME LEI 8.213/91.
}

\author{
Juliano Ribeiro Machado ${ }^{1}$ \\ Cleiton Franco $^{2}$ \\ Eder Eugenio Munhão ${ }^{3}$ \\ Sandra Maria de Faria ${ }^{4}$
}

\begin{abstract}
RESUMO
O presente estudo tem como objetivo demonstrar a realidade do mercado de trabalho para a pessoa com deficiência física, com relação às vagas previstas na Lei 8.213/91, Art. 93, e a demanda das pessoas com deficiência física em Tangará da Serra - MT, sob a ótica do processo de inclusão nas empresas, as quais se enquadram na referida lei. Para que o estudo atingisse tal objetivo foram utilizados procedimentos metodológicos de revisões bibliográficas. A fim de buscar dados práticos foram aplicados questionários para 41 (quarenta e uma) pessoas com deficiência física, membros da Associação Tangaraense de Deficientes Físicos presentes na reunião ordinária realizada no dia 23/09/2013, e as empresas com 100 (cem) ou mais funcionários (dentre estas está obrigada a preencher os percentuais exigidos pela lei de cotas), buscando uma visualização mais abrangente sobre a inclusão social. Os resultados mostram um crescimento perceptível de pessoas com deficiência no município de Tangará da Serra. Ao mesmo tempo os deficientes físicos avaliam a acessibilidade nas empresas e comércios como ruim e péssimo, afinal grande parte dessas pessoas tem limitações que podem ser superadas num ambiente adequado. Já para as empresas há dificuldade em encontrar deficientes físicos para o mercado de trabalho. Todavia, vale ressaltar que, as empresas, devem praticar a inclusão social, destacando a acessibilidade, estando preparadas para atender as especificidades deste público.
\end{abstract}

Palavras-chave: Inclusão Social. Deficiente. Mercado de Trabalho.

\section{INTRODUÇÃ̃O}

No Brasil, os dados do Instituto Brasileiro de Geografia e Estatística (IBGE), realizado em 2000, indicou um percentual de 14,55\%, isso é, no referido ano, 24.600 .256 pessoas assinaram ter algum tipo de deficiência ou incapacidade. Em relação ao último Censo Demográfico, realizado em 2010, há um expressivo crescimento no número de pessoas que

\footnotetext{
${ }^{1}$ Acadêmico do curso de Ciências Contábeis da UNEMAT - Campus de Tangará da Serra, e-mail: jrmtga@ hotmail.com.

${ }^{2}$ Mestre em Economia pela Universidade Federal de Mato Grosso (2009) com ênfase em agronegócios, Professor do curso de Ciências Contábeis da UNEMAT - Campus de Tangará da Serra, e-mail: cleitonfranco@ unemat.br.

${ }^{3}$ Mestre em Ciências Contábeis UNISINOS/UNEMAT, e-mail: edermunhao@ unemat.br.

${ }^{4}$ Graduada em Ciências Contábeis pela UNEMAT - Campus de Tangará da Serra, e-mail: Sandra.faria@unemat.br. 
A pessoa com deficiência física e o mercado de trabalho: estudo empírico no município de Tangará da Serra-MT, dos afiliados da ASTANDEF e empresas inseridas no regime de cotas conforme Lei 8.213/91. Juliano Ribeiro Machado Cleiton Franco

Eder Eugenio Munhão Sandra Maria de Faria

declararam algum tipo de deficiência ou incapacidade, de acordo com o mesmo, 45,6 milhões de brasileiros, $24 \%$ da população, têm alguma deficiência, segundo dados do próprio IBGE a deficiência motora apareceu como a segunda mais relatada pela população, 7\% dos brasileiros mais de 13,2 milhões de pessoas afirmou ter deficiência física. O referido Censo releva também que o município de Tangará da Serra tem 16.725 (dezesseis mil setecentos e vinte e cinco) pessoas com deficiência (PcD), ou seja, 20,76\% da população apresenta, pelo menos, uma deficiência. A deficiência motora foi declarada por 4.600 (quatro mil e seiscentas) pessoas, destas, 239 (duzentas e trinta e nove), disseram não caminhar ou subir escadas de modo algum, e mais de 4.361 (quatro mil trezentos e sessenta e um), informaram ter grande dificuldade de locomoção avaliada com o uso de prótese, órtese, bengala ou aparelho auxiliar, no caso de utilizá-los, (IBGE, 2010).

$\mathrm{Na}$ supramencionada, cidade há Associação Tangaraense de Deficientes Físicos (ASTANDEF) fundada no ano de 2004 com 64 associados conforme descrito na ata de fundação. Hoje a associação encontra-se com 362 (trezentos e sessenta e duas) pessoas cadastradas com deficiência física motora, descrito na Classificação Internacional de Doenças (CID) comprovado por laudo médico anexado as fichas de cada associado (ASTANDEF, 2013).

A inclusão dessa categoria na sociedade é um movimento relativamente recente que surgiu no Brasil a partir da década de 80 com a Lei 7.853 de 24 de outubro de 1989 (BRASIL, 1989). $\mathrm{Na}$ verdade a própria $\mathrm{CF} / 88$ já enfatiza os direitos iguais aos trabalhadores com deficiência, determinado no art. 71, inciso XXXI "proibição de qualquer discriminação no tocante a salário ou critérios de admissão do trabalhador com deficiência" (BRASIL, 1988).

As pessoas com deficiência possuem uma vida sofrida e esse sofrimento ocorre da combinação de suas limitações com os obstáculos criados pela sociedade (PASTORE, 2007). Já Omote (2003), relata que o entendimento que a sociedade tem sobre a deficiência pode influenciar nas relações sociais e, também, orientar as ações planejadas e praticadas em relação à pessoa com a deficiência, até mesmo à empregabilidade deste. Dessa maneira Telford (1978), acredita que todas as atividades que visam o desenvolvimento global do individuo vão refletir direta e indiretamente na sua capacitação para uma vida independente, produtiva e integrada socialmente. 
A pessoa com deficiência física e o mercado de trabalho: estudo empírico no município de Tangará da Serra-MT, dos afiliados da ASTANDEF e empresas inseridas no regime de cotas conforme Lei 8.213/91. Juliano Ribeiro Machado Cleiton Franco

Eder Eugenio Munhão

Sandra Maria de Faria

Logo, a abertura do mercado de trabalho para a pessoa com deficiência resulta em diversos aspectos positivos, em especial na integração à sociedade, proporcionando sua independência econômica, social e cultural (SENAC, 2002).

O presente estudo se faz relevante, pois é época de despertar novas preocupações sociais visando superação. Questões relativas aos problemas sociais, ambientais, econômicos e humanitários estão emergindo com força em resposta aos efeitos provocados por diversos fatores, dentre eles a globalização (PASTORE 2000).

Esta reflexão vem de encontro com a Contabilidade Social, pois, a mesma evidencia as medidas adotadas e os resultados alcançados pela empresa no processo de Responsabilidade Social. Para Ribeiro (1992), a contabilidade social é instrumento de comunicação entre empresas e sociedade. Sendo assim, o ramo da contabilidade tende a conhecer nos dias atuais a realidade sobre a situação do mercado de trabalho para a pessoa com deficiência física.

De acordo com descrito acima, objetivo geral da pesquisa é averiguar a realidade do mercado de trabalho para a pessoa com deficiência física, com relação às vagas previstas em lei, e a demanda dos mesmos em Tangará da Serra - MT. Especificamente procurou-se: 1) Pesquisar se as empresas estão atentas aos procedimentos de contratação exigidos pela lei 8.213/91 também conhecida como a "Lei de Cotas", especialmente a do seu Art. 93, com definições estabelecidas na Convenção $\mathrm{n}^{\circ}$. 159 da Organização Internacional do Trabalho (OIT), Parte I, Decreto n $3.298 / 99$, Arts. $3^{\circ}$ e $4^{\circ}$ com alterações dadas pelo Art. 70 do Decreto $\mathrm{n}^{\circ}$ 5.296/04, para que contratador possa ser legalmente enquadrado na lei supracitada; 2) Verificar com as pessoas com deficiência física qual o nível de conhecimento a respeito da lei de cotas.

Nessa linha de pensamento, pretende-se com o presente artigo responder ao seguinte questionamento: Quais são as dificuldades que as pessoas com deficiência física encontram para sua inclusão no mercado de trabalho em Tangará da Serra/MT?

Justifica-se esta pesquisa em razão da existência de diversos estudos sobre inclusão de pessoas com deficiência no mercado trabalho: Oportunidades de trabalho para pessoas com deficiência (PASTORE, 2000), Inclusão da pessoa com deficiência física no mercado de trabalho: Um estudo de caso na Associação baiana de deficientes físicos (ABADEF), (FIGUEIREDO, 2010), Inclusão de pessoas com deficiência no mercado de trabalho (SENAC DN RS, 2002), Pessoas com deficiência a questão da inclusão social (MACIEL, 2000). No 
A pessoa com deficiência física e o mercado de trabalho: estudo empírico no município de Tangará da Serra-MT, dos afiliados da ASTANDEF e empresas inseridas no regime de cotas conforme Lei 8.213/91. Juliano Ribeiro Machado Cleiton Franco

Eder Eugenio Munhão Sandra Maria de Faria

entanto, nada se sabe sobre a situação do mercado de trabalho para a pessoa com deficiência física em Tangará da Serra - MT.

\section{REFERENCIAL TEÓRICO}

\subsection{Responsabilidade Social da Empresa (RSE)}

Esta cada vez mais difundida, nos vários setores da sociedade, a ideia de que a atual situação do mundo requer atenção especial das empresas para sua dimensão social (BALDO, 2002).

A Responsabilidade Social da empresa (RSE) é um movimento que iniciou nos anos 1960. Sua proliferação se deu a partir dos EUA e a motivação se fundamentou na busca por maior consciência de segmentos da sociedade em relação à responsabilidade das empresas na preservação do meio ambiente e dos direitos dos consumidores. No decorrer dos últimos 20 anos do século XX, em função de novas demandas decorrentes de transformações ocorridas no panorama econômico mundial, a noção de RSE passou a abranger um conjunto bem mais amplo de ações, entre as quais as demandas sociais originadas em populações em condições de vulnerabilidade social (REIS; MEDEIROS, 2009).

A responsabilidade social é uma forma de conduzir os negócios da empresa de tal maneira que a torna parceira e corresponsável pelo desenvolvimento social. A empresa socialmente responsável é aquela que possui a capacidade de ouvir os interesses das diferentes partes, (acionistas, funcionários, prestadores de serviço, fornecedores, consumidores, governo e meio ambiente) e conseguir incorporá-los no planejamento de suas atividades (ALLESSIO, 2003).

Para Martinelli (1997), a correta prática da responsabilidade social pode melhorar o desempenho e a sustentabilidade a médio e longo prazo da empresa, proporcionando: valor agregado à imagem corporativa da empresa; motivação do público interno; vantagem competitiva; facilidade no acesso ao capital e financiamento; reconhecimento dos dirigentes como líderes empresariais; melhoria organizacional; dentre outros.

A sociedade está cada vez mais disposta a comprar produtos de empresas responsáveis, o que vem demonstrando uma importante ferramenta de marketing para as 
A pessoa com deficiência física e o mercado de trabalho: estudo empírico no município de Tangará da Serra-MT, dos afiliados da ASTANDEF e empresas inseridas no regime de cotas conforme Lei 8.213/91. Juliano Ribeiro Machado Cleiton Franco

Eder Eugenio Munhão Sandra Maria de Faria

empresas, os consumidores são fiéis para com as empresas que possuem uma marca que traz à memória o respeito ao ser humano e ao meio ambiente (FELIX, 2005).

Na opinião de Tachizawa (2004), a responsabilidade social está se transformando num parâmetro, e referencial de excelência, para o mundo dos negócios e para todo o Brasil corporativo. As empresas tem que procurar demonstrar à sociedade que não se avança sem a dignidade da população, as organizações socialmente responsáveis devem abordar suas responsabilidades perante a sociedade e o exercício da cidadania, por meio de estágios que vão desde uma fase embrionária até sua fase mais avançada.

Frente a todas essas questões, destaca-se a importancia da responsabilidade social da empresa para a inclusão da PcD visando desenvolvimento de politicas de promoção e respeito à diversidade na sociedade, sendo assim, não se trata, portanto, somente de contratar pessoas com deficiência, mas também de oferecer as possibilidades para que possam desenvolver seus talentos e permanecer na empresa, atendendo aos critérios de desempenho previamente estabelecidos (INSTITUTO ETHOS, 2002).

\subsection{Inclusão Social}

A inclusão social é o ato ou efeito de incluir, quer dizer inserir, fazer parte (FERREIRA, 1986). Assim à inclusão social é um processo de conquista por direitos igualitários na vida social, econômica e política, é combater a exclusão geralmente provocada pela vida social.

Segundo Sassaki (2006), inclusão social é o processo pelo qual a sociedade se adapta para que possa incluir pessoas e grupos em seus sistemas sociais. Para Rodrigues (2005), a inclusão é o crescimento de todos no respeito à diferença, no convívio com a diversidade. Já Mantoan (2000) inclusão é a capacidade de entender e reconhecer o outro e, assim, ter o privilegio de conviver e compartilhar com pessoas diferentes. Moreira (2006), a inclusão social pode ser entendida como a ação de proporcionar para as populações que são socioeconomicamente excluídas, em um sentindo amplo de educação formal, qualificação profissional, habilitação e reabilitação para o trabalho.

Os autores apresentam ideias semelhantes, dirigem-se a questão da inclusão social como ideia positiva, em suma, contribui num esforço coletivo em busca de respeito, liberdade 
A pessoa com deficiência física e o mercado de trabalho: estudo empírico no município de Tangará da Serra-MT, dos afiliados da ASTANDEF e empresas inseridas no regime de cotas conforme Lei 8.213/91. Juliano Ribeiro Machado Cleiton Franco

Eder Eugenio Munhão Sandra Maria de Faria

e da igualdade de todos, inclusive das $\mathrm{PcD}$, sendo ações que visem à inclusão daqueles excluídos afastados da realidade social.

No que tange o assunto às oportunidades e condições tem que ser iguais e incorporadas a toda população para viver com adequada qualidade de vida e como cidadãos plenos, dotados de conhecimentos, meios e mecanismos de participação política que os capacitam a agir de forma digna, fundamentada e consciente.

Na realidade para a pessoa com deficiência as demandas por inclusão social são muito críticas, pois, a estrutura da sociedade atual atende às necessidades de pessoas não deficientes, enquanto que o deficiente não tem acesso muitas vezes por limitação física, e a falta de acessibilidade, até mesmo das próprias empresas, portanto, lutar a favor da inclusão social deve ser responsabilidade de cada um e de toda sociedade (MACIEL, 2000).

\subsection{Deficiente Físico e o Mercado de Trabalho}

Para melhor entendimento do assunto, primeiramente será apresentado o conceito de pessoa com deficiência. Ao longo dos anos teve diversas denominações para se referir as pessoas com deficiência - auditiva, visual, mental e motora. A expressão mais utilizada era "pessoa portadora de deficiência", a condição de ter uma deficiência faz parte da pessoa e esta não porta sua deficiência, ela tem uma deficiência. A Presidência da Republica através da Secretaria de Direitos Humanos definiu pela portaria 2.344, publicada no Diário Oficial da União no dia 05 de novembro de 2010 o termo correto para o tratamento das pessoas com deficiência. O Art. $2^{\circ}$ atualiza a nomenclatura do Regimento Interno do CONADE, aprovado pela Resolução $\mathrm{n}^{\mathrm{o}} 35$, de 6 de julho de 2005, foi retirado oficialmente do termo a palavra "portador", onde se lê "Pessoas Portadoras de Deficiência, leia-se "Pessoas com Deficiência" (PORTARIA nº 2.344/2010).

A Organização Internacional do Trabalho (OIT) em convenção n $^{\circ} .159$ de 1983, aprovada pelo Brasil através do Decreto Legislativo no 51, de 28 de agosto de1989 conceitua pessoa com deficiência no art. 11, da seguinte forma:

Para efeitos da presente Convenção, entende-se por pessoa deficiente todo indivíduo cujas possibilidades de obter e conservar um emprego adequado e de progredir no mesmo fique substancialmente reduzido devido a uma deficiência de caráter físico ou mental devidamente reconhecida.

Ainda segundo Fonseca (2000) o conceito em questão ressalta o caráter funcional das deficiências físicas ou sensoriais, estabelecendo a Convenção o dever dos países signatários 
A pessoa com deficiência física e o mercado de trabalho: estudo empírico no município de Tangará da Serra-MT, dos afiliados da ASTANDEF e empresas inseridas no regime de cotas conforme Lei 8.213/91.

Juliano Ribeiro Machado

Cleiton Franco

Eder Eugenio Munhão

Sandra Maria de Faria

de se engajarem em atividades de integração e de fornecerem instrumentos que viabilizem o exercício das atividades profissionais para as pessoas que deles necessitem.

Quanto ao tipo de deficiência física no Decreto 3.298/99 art. $3^{\circ}$ define deficiência como toda perda ou anormalidade de uma estrutura ou função psicológica, fisiológica ou anatômica que gere incapacidade para o desempenho de atividade, dentro do padrão considerado normal para o ser humano (BRASIL, 1999).

As informações até então pesquisadas é fato que para as PcD o trabalho é uma forma de reconhecimento como parte atuante neste mundo de valorização de potencias motora, levando a constituir um dos meios que viabiliza o processo de adaptação e integração numa sociedade competitiva.

Nesse sentido a Constituição Federal de 1988 é clara no proposito de possibilitar que as PcD passem a ser vistos de forma participativa no mercado de trabalho, mesmo assim, não se pode afirmar que essa contratação é por entender que a pessoa com deficiência faça parte da sociedade como um individuo, mas por força da lei.

Em decorrência, a Lei $\mathrm{N}^{\mathrm{o}} 7.853 / 89$, que dispõe sobre o apoio às pessoas com deficiência, sua integração social, sobre a Coordenadoria Nacional para Integração da mesma, ao estabelecer que:

III - na área da formação profissional e do trabalho:

a) o apoio governamental à formação profissional, e a garantia de acesso aos serviços concernentes, inclusive aos cursos regulares voltados à formação profissional;

b) o empenho do Poder Público quanto ao surgimento e à manutenção de empregos, inclusive de tempo parcial, destinados às pessoas com deficiência que não tenham acesso aos empregos comuns;

c) a promoção de ações eficazes que propiciem a inserção, nos setores público e privado, de pessoas com deficiência;

$\mathrm{O}$ artigo supramencionado, de forma expressa, visa garantir apoio dos governantes deste a qualificação até sua inclusão no mercado de trabalho, ficando claro o interesse do legislador ordinário infraconstitucional em querer tutelar aqueles com maior vulnerabilidade, garantindo-lhes melhores condições de acessibilidade em locais públicos, eliminando os obstáculos arquitetônicos e as barreiras.

Representando a posição mais atual da OIT, seu principio basilar esteia-se na garantia de um emprego adequado e na possibilidade de integração ou reintegração das pessoas com deficiência na sociedade (OIT, 2012).

Além de algumas empresas se enquadrarem na lei 8.213/91, que dispõe sobre os planos de benefícios da Previdência e dá outras providencias a contratação de deficientes, em seu art. 93, determina que as empresas com 100 ou mais funcionários devem preencher de $2 \%$ 
A pessoa com deficiência física e o mercado de trabalho: estudo empírico no município de Tangará da Serra-MT, dos afiliados da ASTANDEF e empresas inseridas no regime de cotas conforme Lei 8.213/91.

Juliano Ribeiro Machado

Cleiton Franco

Eder Eugenio Munhão

Sandra Maria de Faria

a 5\% dos seus cargos com beneficiários reabilitados ou pessoas com deficiência. Ainda segundo o referido artigo a empresa com até 200 funcionários tem que ter $2 \%$ de suas vagas preenchidas por pessoas com deficiência; entre 201 a 500 funcionários, 3\%; de 501 a 1000 funcionários, 4\%, empresas de 1001 funcionários em diante, 5\% das vagas (BRASIL, 1991).

Seguindo o mesmo artigo, no primeiro paragrafo, a dispensa do trabalhador reabilitado ou de deficiente habilitado ao final de contrato por prazo determinado de mais de 90 (noventa) dias, e a imotivada, no contrato por prazo indeterminado, só poderá ocorrer após a contratação de substituto de condição semelhante.

É sábio que a pessoa com deficiência física tem limitações motoras, muitas vezes tem dificuldades de circular pelas ruas da cidade, utilizar o transporte coletivo ou entrar em estabelecimentos públicos e privados, sendo obrigada, muitas vezes, a exclusão social, deixam de exercer seu direito de ir e vir, esse direito é primordial para inclusão de qualquer cidadão.

Ford (1954, p.11), declara que:

Um cego ou um mutilado é capaz de efetuar o mesmo trabalho e ganhar o mesmo salário de um homem completamente são. Seria inteiramente oposto aos nossos fins que procurássemos dar colocação aos operários em vista dos seus defeitos físicos, com salário reduzido, contentando-nos com um tipo baixo de produção. É um desperdício empregar um homem perfeito num trabalho que pode ser executado por um deficiente.

A competência profissional das pessoas com deficiência, respeitando-se suas limitações, pode ser desenvolvida em todos os campos do mercado de trabalho: indústria, serviços, cargos públicos e comercio, dentre outros (SENAC, 2002). É importante ressaltar a promoção da acessibilidade como meio de oportunidade para as $\mathrm{PcD}$ de participarem plenamente na sociedade, em iguais condições com as demais.

\section{METODOLOGIA}

Ribeiro, Torres e Rocha (2006, p.190) afirmam que: "método é o caminho a ser seguido a fim de que as metas sejam atingidas. Portanto, a seleção do instrumento metodológico esta diretamente relacionada ao problema a ser estudado".

Quanto à abordagem do problema utilizou-se da pesquisa qualitativa e quantitativa. Por meio do modelo qualitativo procurou descrever a realidade encontrada, possibilitando uma análise em maior profundidade.

De acordo com Beuren (2006, p.92) "na pesquisa qualitativa concebem-se análises mais profundas em relação ao fenômeno que está sendo estudado". A abordagem qualitativa 
A pessoa com deficiência física e o mercado de trabalho: estudo empírico no município de Tangará da Serra-MT, dos afiliados da ASTANDEF e empresas inseridas no regime de cotas conforme Lei 8.213/91. Juliano Ribeiro Machado Cleiton Franco

Eder Eugenio Munhão

Sandra Maria de Faria

visa destacar características não observadas por meio de um estudo quantitativo, haja vista a superficialidade deste último, ou seja, foram considerados os dados em profundidade a fim de investigar quais são as dificuldades que as pessoas com deficiência física encontram para sua inclusão no mercado de trabalho em Tangará da Serra/MT, partindo desde a acessibilidade arquitetônica até a adaptação de suas atividades profissionais dentro da empresa.

Já a quantitativa foi utilizada para análise e interpretação dos resultados. As coletas foram através de questionários, contendo 15 (quinze) questões fechadas e 02 (dois) abertas para as pessoas com deficiência física e 17 (dezessete) questões para as empresas, averiguando a inserção das pessoas com deficiência física no mercado de trabalho de Tangará da Serra, cujo roteiro foi constituído a partir dos vários fatores identificados no referencial teórico deste estudo.

Quanto aos fins, em relação aos objetivos da pesquisa, a metodologia utilizada tomou como base a pesquisa documental e estudo de caso. A pesquisa documental justifica-se pela análise a ser realizada em documentos da ASTANDEF como, atas, estatutos, regimentos e fichas de cadastro visando identificar o total de pessoas com deficiência física associada, e se a associação tem algum projeto de inclusão dos mesmos no mercado de trabalho do referido município, entre outros, relatórios que fossem necessários para esclarecimento de dados ou fatos. Segundo Vergara (2007) a investigação documental é realizada em documentos conservados no interior de órgãos públicos ou privados de qualquer natureza.

Já o estudo de caso aprofunda a ideia de que se pretende chegar, tendo um tema onde o estudo busca investigar a inclusão da pessoa com deficiência física no mercado de trabalho de Tangará da Serra, enfatizando as barreiras e as legislações vigentes. Gil (1995) aponta algumas vantagens do estudo de caso que são: estímulo a novas descobertas, uma ênfase na totalidade e a simplicidade dos procedimentos.

Quanto aos meios, para alcançar os objetivos fez-se necessário à utilização da pesquisa bibliográfica que, conforme Gil (1995, p.48) “é desenvolvida a partir de material já elaborado, constituído principalmente de livros científicos", é contato direto com as bibliografias escritas sobre o assunto, como: artigos, livros, dissertações e textos. Além dos referenciais teóricos, buscaram-se subsídios para compreensão e discussão através das leis pertinentes ao tema.

A pesquisa telematizada apoia-se no conteúdo disponível via internet, que Vergara (2007, p.46) a conceitua como “(...) busca de informações em meios que combinam o uso do 
A pessoa com deficiência física e o mercado de trabalho: estudo empírico no município de Tangará da Serra-MT, dos afiliados da ASTANDEF e empresas inseridas no regime de cotas conforme Lei 8.213/91. Juliano Ribeiro Machado Cleiton Franco

Eder Eugenio Munhão Sandra Maria de Faria

computador e de telecomunicações", foi pesquisado "site" de recenseamento demográfico, IBGE, para saber a população brasileira de pessoas com deficiência.

Para Vergara (2007), a investigação é empírica, realizada no local que ocorre ou ocorreu um fenômeno ou que dispõe de elementos para explicá-lo. Para Pereira (2007) o levantamento é utilizado quando envolve a interrogação direta das pessoas, cujo comportamento se deseje conhecer.

O levantamento de dados foi realizado via contato pessoal com as pessoas com deficiência física e os empresários que contratam essas pessoas para a mão-de-obra, informando a todos sobre o objetivo da pesquisa. Para a coleta de dados com as pessoas com deficiência física foi utilizado questionário com questões fechadas e abertas investigando quais são as dificuldades encontradas para sua inclusão no mercado de trabalho de Tangará da Serra, analisando o conhecimento dos mesmos a respeito da lei de cotas. Nas empresas foi adotado o método de entrevista com roteiro estruturado, para identificar se tais empresas estão atentas aos procedimentos de contratação exigidos pela referida Lei de Cotas. A entrevista é um procedimento no qual se faz perguntas e alguém que, oralmente, lhe responde, a presença física de ambos é necessária no momento da entrevista (VERGARA, 2007).

Para a realização da pesquisa os questionários foram aplicados em períodos diferentes, entre os dias 23 e 25/09/2013, com 41 associados, seguindo o padrão estatístico chamado de Intervalo de Confiança, conforme Anderson, et al (2005) um intervalo de confiança é um intervalo estimado de um parâmetro de interesse de uma população. Em vez de estimar o parâmetro por um único valor, é dado um intervalo de estimativas prováveis. O quanto estas estimativas são prováveis será determinado pelo coeficiente de confiança. Com uma margem de erro de $12 \%$ para uma população de 361 pessoas, e um nível de confiança de 90\%, obtivemos nossa amostra de 41 pesquisados, os quais foram todos entrevistados durante reunião extraordinária da associação ASTANDEF, o presidente da associação senhor Rodrigo Rodrigues relatou sobre as dificuldades de locomoção dos associados, tendo em vista que a associação não possui sede própria, e conta apenas com o apoio de outras entidades as quais disponibilizam seu espaço para a realização das assembleias, na maioria das vezes esses espaços não comportam todos os associados nem dá condições de acessibilidade a todos, acredita ainda que se a associação tivesse um espaço próprio e adequado poderia haver um maior número de pessoas com deficiência física atuantes nas reuniões e assembleias. As empresas foram escolhidas de forma aleatória, sendo que todas são empresas privadas e tem 
A pessoa com deficiência física e o mercado de trabalho: estudo empírico no município de Tangará da Serra-MT, dos afiliados da ASTANDEF e empresas inseridas no regime de cotas conforme Lei 8.213/91. Juliano Ribeiro Machado Cleiton Franco

Eder Eugenio Munhão Sandra Maria de Faria

cadastro ativo no Posto do Sistema Nacional de Empregos (SINE) de Tangará da Serra, as informações repassadas pela entidade dão conta que poucas empresas tangaraenses que encaixam na Lei de Cotas, o qual possibilitou a utilização de uma amostra de 17 (dezessete) empresas, sendo que deste total apenas 09 (nove) responderam ao questionário, o qual busca uma visualização mais abrangente sobre a inclusão social, dentre estas empresas que responderam aos questionamentos todas estão obrigadas a preencher os percentuais exigidos pela lei de cotas.

Contribuíram com as informações os gerentes, administradores e proprietários das empresas entrevistadas, desde que fossem os responsáveis pela contratação desses colaboradores. Os resultados obtidos foram demonstrados considerando sua profundidade e relevância. Para tal foram utilizados quadros, tabelas e textos explicativos com a finalidade de estabelecer comparativos entre as diversas concepções dos sujeitos pesquisados, sendo fundamentado por pesquisas relacionadas ao tema.

\section{RESULTADOS}

Esta seção tem por finalidade a apresentação e discussão dos resultados obtidos na pesquisa, através de questionamentos aplicados à população amostral. Tendo em vista que o CENSO 2010 identificou 4.600 pessoas com deficiência física em Tangará da Serra - MT, o que revela uma demanda de trabalhadores para as vagas em aberto. Sendo assim, considerando as informações repassadas pelo senhor Marco Antônio de Souza chefe do SINE, onde são disponibilizadas publicações atualizadas de empregos, há cerca de 150 (cento e cinquenta) vagas para pessoas com deficiência e para pessoas "não deficientes" chegam a 160 vagas, as vagas destinadas para pessoa com deficiência foram solicitadas justamente pelas empresas que são obrigadas a preencher os percentuais exigidos pela lei de cotas, estima-se que Tangará da Serra possua cerca de 130 pessoas com deficiência empregadas e atuando no mercado de trabalho (SINE, 2013). Com base nessas informações conclui que a oferta total de emprego para o deficiente em Tangara da Serra é de 280 vagas.

\subsection{Perfil das empresas que se enquadram aos procedimentos de contratação exigidos pela lei 8.213/91 "Lei de Cotas".}

Os resultados foram apresentados por quadros e tabelas, discutidos através da comparação dos resultados percentuais das respostas. Primeiramente, buscou-se conhecer o 
A pessoa com deficiência física e o mercado de trabalho: estudo empírico no município de Tangará da Serra-MT, dos afiliados da ASTANDEF e empresas inseridas no regime de cotas conforme Lei 8.213/91.

Juliano Ribeiro Machado

Cleiton Franco

Eder Eugenio Munhão

Sandra Maria de Faria

ramo de atividade de cada empresa pesquisada, o total de funcionários e quantos tem incluído com deficiência e que funções exercem.

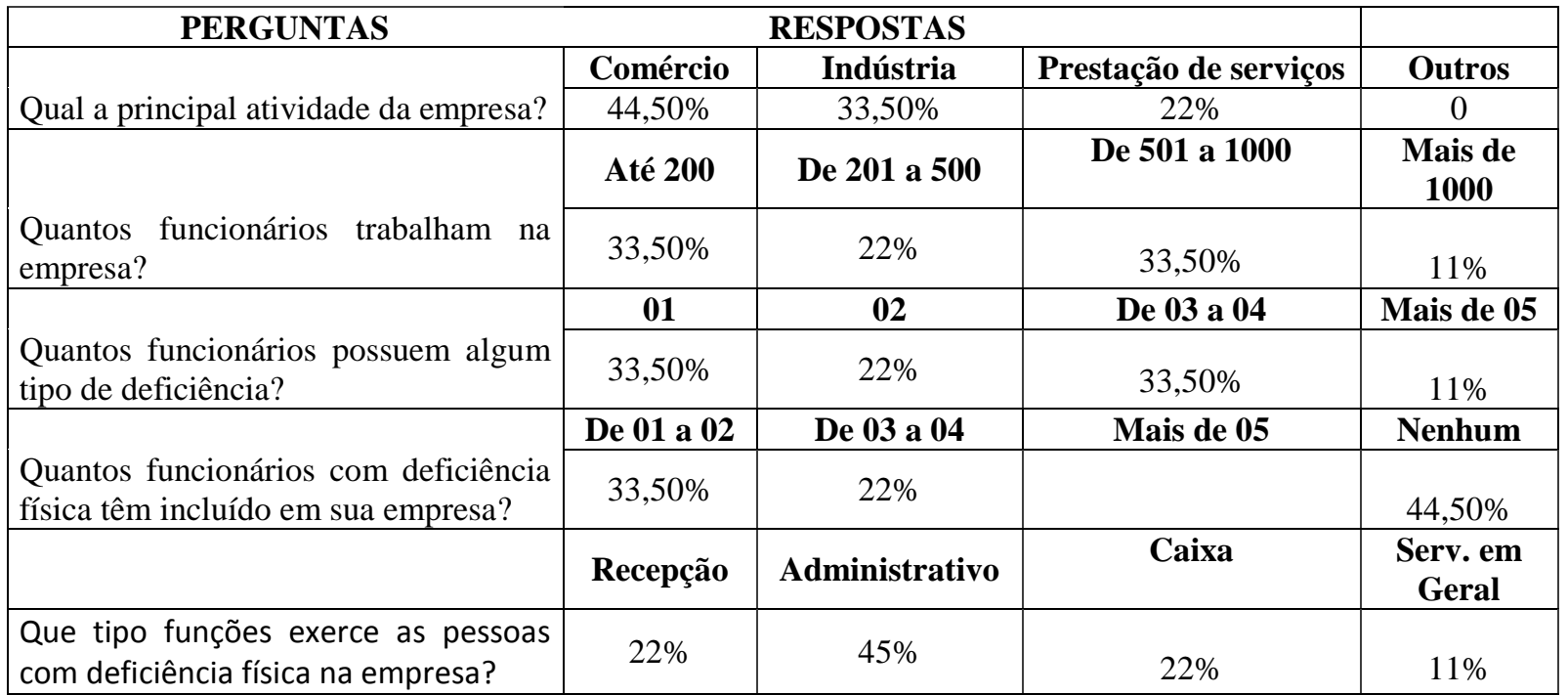

Quadro 1. Perfil das empresas por ramo de atividade, quantidade de funcionários com deficiência e funções que exercem.

Entre as empresas, destacaram três ramos de atividades, 44,50\% sendo comercio em geral, as demais foram variadas entre indústria com 33,50\% e prestação de serviços $22 \%$ como demostrado no quadro acima.

Dentre estas, variam muito o número de funcionários, apresentando os seguintes percentuais: 33,50\% têm até 200 funcionários, $22 \%$ entre 201 a 500, de 501 a 1000 com 33,50\%, observa-se que apenas $11 \%$ têm mais de 1000 funcionários. Em meio às informações procurou-se saber quantos funcionários as empresas possuem com alguma deficiência, $33,50 \%$ possui 1 (um) funcionário, 22\% contam com 2(dois), 33,50\% de 03 (três) a 04 (quatro) colaboradores com algum tipo de deficiência e 11\% mais de cinco colaboradores. Dentre as empresas pesquisadas $44,50 \%$ responderam não ter nenhuma pessoa com deficiência física em seu quadro de funcionários.

Em relação à função exercida na empresa, as que mais se destacaram foram no setor administrativo com $45 \%$ das respostas, identificando o perfil da pessoa com deficiência física ao cargo que é ocupado, enquadrando o mesmo em um setor onde sua capacidade é desenvolvida e apreciada, sempre visando se há dificuldade de desempenhar as funções que lhe são atribuídas.

Na pesquisa de Figueiredo (2010), sobre a temática "o deficiente físico no mercado de trabalho", sob a ótica do processo de inclusão contemporaneidade que estuda o caso da 
A pessoa com deficiência física e o mercado de trabalho: estudo empírico no município de Tangará da Serra-MT, dos afiliados da ASTANDEF e empresas inseridas no regime de cotas conforme Lei 8.213/91. Juliano Ribeiro Machado Cleiton Franco

Eder Eugenio Munhão Sandra Maria de Faria

Associação Baiana de Deficientes Físicos visando conhecer a vida daquelas pessoas. Informa que as ocupações são mais realizadas para quem tem o $2^{\circ}$ grau como a função de auxiliar administrativo, o referido autor também cita que a eliminação das barreiras, ou seja, a acessibilidade é a forma de inclusão primordial, pois a pessoa com DF já sai de casa sem ficar preocupada como chegar e, quando chegar ao trabalho, que condições têm a empresa para fazer sua integração.

Segundo Carvalho-Freitas (2007), a gestão da diversidade das pessoas com deficiência é marcada, principalmente, por três dificuldades: a forma como os gestores enxergam a deficiência, a adequação das condições e práticas do trabalho por parte das empresas, e a necessidade de avaliar a satisfação dos empregados com deficiência.

O Ministério do Trabalho e Emprego (2007), ao editar cartilha com informações para empregadores e pessoas com deficiência assim se expressa com relação à responsabilidade social: Para a empresa socialmente responsável, a contratação das pessoas com deficiência não é vista apenas como uma obrigação legal. A inclusão, para essas empresas, passa a ser um compromisso e um dos itens de sua política de responsabilidade social, nesse sentido a tabela 1 apresenta o percentual de importancias dada pela empresa para está responsabilidade, observar-se que, 67\% (sessenta e sete por cento) das respostas consideram importante a responsabilidade social da empresa, e $22 \%$ muito importante. Numa pesquisa realizada por Leite (2012), sobre a inclusão do deficiente auditivo no mercado de trabalho em Tangará da Serra, na questão sobre a contratação do deficiente auditivo acontece por responsabilidade social ou força da lei, 66,67\% respondeu que contratam os deficientes auditivos pela obrigatoriedade da lei, de modo que prevalece o que determina a lei.

Tabela 1. Respostas à questão: Que grau de importância é dado pela empresa à Responsabilidade Social:

\begin{tabular}{|c|c|}
\hline Alternativas & Respostas\% \\
\hline Muito Importante & $22 \%$ \\
\hline Importante & $67 \%$ \\
\hline Pouco Importante & $11 \%$ \\
\hline Sem importância & $0 \%$ \\
\hline Total & $100 \%$ \\
\hline
\end{tabular}

Fonte: Dados da Pesquisa

Com a aplicação da pesquisa buscou-se saber a percepção das empresas que contratam pessoas com deficiência física, foram constatados os resultados descritos na entrevista, conforme demonstrado nas tabelas. Foi perguntado para as empresas sobre o conhecimento de onde pode ser encontrados candidatos a emprego com deficiência física, e 78\% das respostas 
A pessoa com deficiência física e o mercado de trabalho: estudo empírico no município de Tangará da Serra-MT, dos afiliados da ASTANDEF e empresas inseridas no regime de cotas conforme Lei 8.213/91. Juliano Ribeiro Machado Cleiton Franco

Eder Eugenio Munhão Sandra Maria de Faria

procuram em instituições representativas das pessoas com deficiência que lhes passam as informações necessárias, apenas $22 \%$ procuram o SINE de Tangará da Serra. Os dados mostram que as empresas não estão conseguindo atingir o percentual exigido por lei, o motivo veremos na tabela 4.

Tabela 2: Respostas à questão: A empresa tem conhecimento onde pode ser encontrados candidatos a emprego com deficiência:

\begin{tabular}{l|c}
\hline \multicolumn{1}{c}{ Alternativas } & Respostas\% \\
\hline Instituições representativas das pessoas com & $78 \%$ \\
deficiência & $22 \%$ \\
Postos do Sistema Nacional de Empregos (SINE) & $0 \%$ \\
Agência de emprego particular & $0 \%$ \\
Serviço Nacional de Aprendizagem Comercial & $\mathbf{1 0 0 \%}$ \\
\hline \multicolumn{1}{c}{ Total } & \\
\hline
\end{tabular}

Fonte: Dados da Pesquisa

A pesquisa buscou identificar se o tipo da deficiência é um fator que interferi no momento da contratação e $77 \%$ respondeu que não, na visão dos gerentes de recursos humano das empresas todos os tipos são avaliados, lembrando que alguns casos dependem do nível da deficiência havendo necessidade de capacitar os lideres. Para Leite (2012) há sim casos que não se podem efetuar contratações, por se tratar de enfermidades consideradas graves, onde pode ocorrer situação de risco tanto para o deficiente quanto para os colaboradores da empresa, por isso antes é necessário fazer recrutamento.

Conforme constatou Rodrigues et al (2009), em sua pesquisa sobre a Deficiência Intelectual: aceitação de trabalho em Tangará da Serra, identificou-se que $80 \%$ dos colaboradores das empresas pesquisadas são deficientes físicos.

Tabela 3. Respostas à questão: O tipo da deficiência foi um fator que interferiu no momento da contratação?

\begin{tabular}{|c|c|}
\hline Alternativas & Respostas\% \\
\hline Sim & $5 \%$ \\
\hline Não & $77 \%$ \\
\hline Não respondeu & $18 \%$ \\
\hline Total & $100 \%$ \\
\hline
\end{tabular}

Fonte: Dados da Pesquisa

Na questão de dificuldades na contratação, as empresas têm com $88 \%$ das respostas a falta de candidatos, as mesmas alegam não encontrar candidatos no mercado de trabalho, muitas vezes chegam a não atingir a cota como pode ser observado no quadro 1 . Visto que as empresas consideram importante a responsabilidade social para empresa, sabem onde encontrar candidatos com deficiência física, mas não encontram candidatos ao mercado de 
A pessoa com deficiência física e o mercado de trabalho: estudo empírico no município de Tangará da Serra-MT, dos afiliados da ASTANDEF e empresas inseridas no regime de cotas conforme Lei 8.213/91. Juliano Ribeiro Machado Cleiton Franco

Eder Eugenio Munhão Sandra Maria de Faria

trabalho. Pastore (2000) nem todo empregador está pronto para entender o problema da pessoa com deficiência para preparar o ambiente de trabalho para a sua inclusão.

Luppi, (2010) ressalta que o mundo das empresas, primeiramente, deve analisar a integração da PcD no mercado de trabalho, sob a ótica das suas qualificações, e não de suas restrições para o trabalho. Quando é solicitado de um profissional o seu currículo, não se pergunta o que ele não sabe fazer. Deseja-se, tão-somente, identificar suas aptidões para compará-las com o perfil do cargo e escolher o melhor profissional.

Tabela 4: Respostas à questão: Quais as maiores dificuldades que a empresa encontrou na contratação da pessoa com deficiência física:

\begin{tabular}{l|c}
\hline \multicolumn{1}{c}{ Alternativas } & Respostas\% \\
\hline Falta de candidatos & $87 \%$ \\
Falta de qualificação profissional dessas pessoas & $2 \%$ \\
Falta de adaptação adequada para atender as & $9 \%$ \\
especificidades deste público: & $2 \%$ \\
\hline \multicolumn{1}{c}{ Outros: } & $\mathbf{1 0 0 \%}$ \\
\hline
\end{tabular}

Fonte: Dados da Pesquisa

O percentual de $77 \%$ apontado na tabela 5 demonstra-se que não houve nenhuma necessidade de mudança de função por parte do trabalho dentro da empresa para a pessoa com deficiência física, as mesmas relataram que há projetos para acessibilidade. No que diz respeito para as pessoas com deficiência a dificuldade para inclusão no mercado de trabalho no referido município como pode ser observado no quadro 6 é a falta de acessibilidade.

Rodrigues et al (2009), expõe em sua pesquisa que a contratação de pessoas com deficiências pode causar ou necessitar de mudanças tanto na parte física da empresa quanto nos demais colaboradores, as pessoas com deficiência em $88 \%$ das empresas também responderam que não provocou nenhuma mudança no ambiente de trabalho.

No que se refere o assunto, à Serasa (Centralização de Serviços dos Bancos S/A) desenvolve trabalho para inclusão de pessoas com deficiência no seu quadro de empregados, a empresa desenvolveu um programa de empregabilidade para PcD, que engloba, além da contratação, a qualificação e capacitação de profissionais para o mercado de trabalho. Trata-se de estágio remunerado de seis meses com o objetivo de efetiva-los na empresa ou, se não for possível qualifica-los profissionalmente para que tenham maior poder de competitividade no mercado de trabalho, a empresa efetuou pequenas adaptações, como modificar banheiros e outros ambientes para facilitar o trabalho. Este posicionamento de inclusão social se traduz em oferecer além de emprego a qualificação, isso é o que realmente que faz a diferença (INSTITUTO ETHOS, 2002). 
A pessoa com deficiência física e o mercado de trabalho: estudo empírico no município de Tangará da Serra-MT, dos afiliados da ASTANDEF e empresas inseridas no regime de cotas conforme Lei 8.213/91. Juliano Ribeiro Machado Cleiton Franco

Eder Eugenio Munhão Sandra Maria de Faria

Tabela 5. Respostas à questão: Houve alguma necessidade de mudança de função por parte do trabalho executado pela pessoa com deficiência física:

\begin{tabular}{|c|c|}
\hline Alternativas & Respostas\% \\
\hline Sim & $3 \%$ \\
\hline Não & $77 \%$ \\
\hline Não respondeu & $20 \%$ \\
\hline Total & $100 \%$ \\
\hline
\end{tabular}

Fonte: Dados da Pesquisa

Foi questionado como a empresa considera a contratação das pessoas com deficiência física pela lei supracitada, as mesmas julgam importante e muito importante por aproximadamente $99 \%$ das respostas esforçam para cumprir a lei em questão, de modo a, respeitar as limitações das PcD. Na pesquisa de Rodrigues et al (2009), foi questionado sobre o conhecimento da lei $8.213 / 91$ e foi identificado que $71 \%$ conhecem a lei, $24 \%$ não conhece e $5 \%$ não responderam.

Souza (2006) verificou que as empresas, para atenderem à Lei de Cotas, estão em busca da "deficiência" e, para isso, renegam a eficiência profissional como primeiro plano. E explica que, nesses casos, a deficiência é considerada como "habilidade", e é ela que importa à empresa, não mais a profissão e a habilidade profissional que a $\mathrm{PcD}$ possui.

Tabela 6. Respostas à questão: Como a empresa considera a contratação das pessoas com deficiência física pela lei 8.213/91:

\begin{tabular}{|c|c|}
\hline Alternativas & Respostas\% \\
\hline Muito Importante & $66 \%$ \\
\hline Importante & $33 \%$ \\
\hline Pouco Importante & $1 \%$ \\
\hline Sem importância & 0 \\
\hline Total & $100 \%$ \\
\hline
\end{tabular}

Fonte: Dados da Pesquisa

As pessoas com deficiência assiste o direito inerente a todo e qualquer ser humano de ser respeitado, sejam quais forem seus antecedentes, natureza e severidade de sua deficiência, têm os mesmos direitos que os outros indivíduos da mesma idade, fato que implica desfrutar de vida decente, tão normal quanto possível (ONU, 1990).

Os dados observados por meio do Quadro 2 apontam que as empresas estão atentas sobre o que rege a lei $8.213 / 91$, respectivamente $89 \%$ responderam que as $\mathrm{PcD}$ não devem ficar em local isolado na empresa, $78 \%$ disseram que o empregado com deficiência contratado por empresa terceirizada não conta para fins de comprovação de preenchimento de conta por parte da tomadora, $89 \%$ concordam na questão da reserva legal ser sobre o número de 
A pessoa com deficiência física e o mercado de trabalho: estudo empírico no município de Tangará da Serra-MT, dos afiliados da ASTANDEF e empresas inseridas no regime de cotas conforme Lei 8.213/91.

Juliano Ribeiro Machado

Cleiton Franco

Eder Eugenio Munhão

Sandra Maria de Faria

empregados do estabelecimento, 67\% consideram que caso a empresa tenha registrado a quantidade de 1000 funcionários é necessário o percentual 5\% de PcD mantidos na empresa precisa manter, e 56\% responderam que o aprendiz com deficiência não conta como preenchimento de cota de PcD. Perguntado as empresas, o que elas entendem por condição semelhante na dispensa imotivada de um funcionário com deficiência contrata-se imediatamente outra pessoa deficiente não importando o tipo de sua deficiência, $85 \%$ respondeu sim. Esta condição está elencada no art. $4^{\circ}$ do Decreto $n^{\circ} 3.298 / 99$, com as alterações efetuadas pelo Decreto $\mathrm{n}^{\circ} 5.296 / 04$.

\begin{tabular}{|c|c|c|c|}
\hline \multirow[t]{2}{*}{$\begin{array}{r}\text { PERGUNTAS } \\
\end{array}$} & \multicolumn{3}{|c|}{ RESPOSTAS } \\
\hline & Sim & Não & Não responderam \\
\hline $\begin{array}{l}\text { Podem os empregados com deficiência ficar em um } \\
\text { setor isolado? }\end{array}$ & & $89 \%$ & $11 \%$ \\
\hline \multirow[b]{2}{*}{$\begin{array}{l}\text { O empregado com deficiência contratado por } \\
\text { empresa terceirizada conta para fins de comprovação } \\
\text { de preenchimento da cota da tomadora? }\end{array}$} & Sim & Não & Não responderam \\
\hline & & $78 \%$ & $22 \%$ \\
\hline \multirow[b]{2}{*}{$\begin{array}{l}\text { A reserva legal de cargos conforme a Lei } 8.213 / 91 \text { é } \\
\text { por percentual sobre o número de empregados do } \\
\text { estabelecimento? }\end{array}$} & Sim & Não & Não responderam \\
\hline & $89 \%$ & & $11 \%$ \\
\hline \multirow[b]{2}{*}{$\begin{array}{l}\text { A empresa tem registrado a quantidade de } 1000 \\
\text { funcionários, o percentual de pessoas com } \\
\text { deficiência que a empresa precisa manter é de } 5 \% \text { ? }\end{array}$} & Sim & Não & Não responderam \\
\hline & $67 \%$ & $1 \%$ & $32 \%$ \\
\hline \multirow[b]{2}{*}{$\begin{array}{l}\text { O aprendiz com deficiência pode contar para cota de } \\
\text { pessoas com deficiência? }\end{array}$} & Sim & Não & Não responderam \\
\hline & $11 \%$ & $56 \%$ & $33 \%$ \\
\hline \multirow[b]{2}{*}{$\begin{array}{l}\text { O que se entende por condição semelhante na } \\
\text { dispensa imotivada de um funcionário com } \\
\text { deficiência, é a contratação imediata de uma pessoa } \\
\text { deficiente não importando sua deficiência? }\end{array}$} & Sim & Não & Não responderam \\
\hline & $85 \%$ & $4 \%$ & $11 \%$ \\
\hline
\end{tabular}

Quadro 2. Percepção das empresas sobre o que rege a lei 8.213/91 "Lei de Cotas".

Para o conhecimento geral, a Câmara Municipal de vereadores de Tangará da Serra aprovou no dia 10 de Outubro de 2013 o projeto de Lei "Empresa Inclusiva", em poucas palavras é um Selo de Reconhecimento para empresas inclusivas de Tangará da Serra. De autoria do vereador Sebastian Ramos, tem como objetivo reconhecer aqueles empresários que trabalham com a causa da deficiência em seu comércio. Um selo de reconhecimento do poder público às empresas que desenvolvem um trabalho voltado para a causa e cumprem a legislação quando o assunto é acessibilidade. Diante disto, um projeto que trataria do reconhecimento dessas empresas que além de garantirem a acessibilidade, ainda tem no seu rol de funcionários, PcD. No entendimento do vereador em questão, o comércio de Tangará 
A pessoa com deficiência física e o mercado de trabalho: estudo empírico no município de Tangará da Serra-MT, dos afiliados da ASTANDEF e empresas inseridas no regime de cotas conforme Lei 8.213/91. Juliano Ribeiro Machado Cleiton Franco

Eder Eugenio Munhão Sandra Maria de Faria

da Serra é grande e forte e a partir disso esse selo irá brindar aqueles empresários, que adequam seus estabelecimentos com rampas e promovem acesso em seu interior, ou seja, cumprem a legislação (PROJETO DE LEI 184/2013).

\subsection{Perfil dos Deficientes Físicos}

Após apresentados os resultados da entrevista com as empresas, segue abaixo respostas das pessoas com deficiência física a respeito de sua visão sobre a inclusão no mercado de trabalho, suas dificuldades e seu conhecimento a respeito da lei de cotas.

\begin{tabular}{|c|c|c|}
\hline \multicolumn{2}{|c|}{ Perfil dos Deficientes Físicos } & \multirow{2}{*}{$\begin{array}{c}\% \\
71 \% \\
29 \% \\
\mathbf{1 0 0 \%} \\
\end{array}$} \\
\hline Gênero & $\begin{array}{l}\text { Masculino } \\
\text { Feminino } \\
\text { Total }\end{array}$ & \\
\hline Idade & $\begin{array}{l}\text { Abaixo de } 20 \text { anos } \\
21 \text { a } 30 \text { anos } \\
31 \text { a } 40 \text { anos } \\
\text { Acima de } 40 \text { anos } \\
\text { Total }\end{array}$ & $\begin{array}{c}6 \% \\
14 \% \\
31 \% \\
49 \% \\
\mathbf{1 0 0 \%}\end{array}$ \\
\hline Grau de Instrução & $\begin{array}{l}\text { Ensino fundamental completo } \\
\text { Ensino médio completo } \\
\text { Ensino superior completo } \\
\text { Total }\end{array}$ & $\begin{array}{c}23 \% \\
30 \% \\
47 \% \\
\mathbf{1 0 0 \%} \\
\end{array}$ \\
\hline $\begin{array}{c}\text { Grau de Instrução } \\
\text { Homens }\end{array}$ & $\begin{array}{l}\text { Ensino fundamental completo } \\
\text { Ensino médio completo } \\
\text { Ensino superior completo } \\
\text { Total }\end{array}$ & $\begin{array}{c}17 \% \\
57 \% \\
26 \% \\
\mathbf{1 0 0 \%}\end{array}$ \\
\hline $\begin{array}{c}\text { Grau de Instrução } \\
\text { Mulheres }\end{array}$ & $\begin{array}{l}\text { Ensino fundamental completo } \\
\text { Ensino médio completo } \\
\text { Ensino superior completo } \\
\text { Total }\end{array}$ & $\begin{array}{r}20 \% \\
80 \% \\
\mathbf{1 0 0 \%} \\
\end{array}$ \\
\hline
\end{tabular}

Quadro 3: perfil dos deficientes físicos por gênero, idade e grau de instrução.

Diante dos dados obtidos, identifica-se no quadro 3 , que $71 \%$ (setenta e um por cento) dos entrevistados são do sexo masculino, nota-se que o número de homens é superior ao de mulheres . Apesar do menor percentual feminino, elas ainda são em maior número com nível superior completo, $80 \%$, o que demonstra uma maior concentração de superação por parte das mulheres. Quanto aos homens 74\% está entre o ensino médio e ensino fundamental completo. Já na pesquisa de Figueiredo (2010), somando-se a escolaridade tanto para feminina quanto masculino, percebeu-se que o $2^{\circ}$ grau é o maior índice de pessoas cadastradas no projeto de inclusão no mercado de trabalho da Associação Baiana de Deficientes Físicos.

\begin{tabular}{|c|c|}
\hline Ocupação Profissional & $\%$ \\
\hline Volume 3, Número 5 & Revista UNEMAT de Contabilidade \\
\hline Jan./Jun. 2014 & UNEMAT \\
\hline
\end{tabular}


A pessoa com deficiência física e o mercado de trabalho: estudo empírico no município de Tangará da Serra-MT, dos afiliados da ASTANDEF e empresas inseridas no regime de cotas conforme Lei 8.213/91. Juliano Ribeiro Machado Cleiton Franco

Eder Eugenio Munhão

Sandra Maria de Faria

\begin{tabular}{|l|c|}
\hline Advogado & $10 \%$ \\
\hline Aposentado & $20 \%$ \\
\hline Auxiliar Administrativo & $15 \%$ \\
\hline Cabelereiro & $07 \%$ \\
\hline Costureira & $02 \%$ \\
\hline Desempregado & $12 \%$ \\
\hline Servidor Público & $17 \%$ \\
\hline Professor (a) & $10 \%$ \\
\hline Técnico em Informática & $05 \%$ \\
\hline Técnico em Telecomunicações & $02 \%$ \\
\hline Total & $\mathbf{1 0 0 \%}$ \\
\hline
\end{tabular}

Quadro 4: Ocupação profissional das Pessoas com Deficiência Física

No quadro 4 procurou-se conhecer a ocupação profissional das pessoas com deficiência física presentes na reunião da ASTANDEF, verificou-se que $20 \%$ dos entrevistados são aposentados faz sentido observa-se que as pessoas com deficiência física estão acima dos 40 anos, o percentual chega a $49 \%$ (quarenta e nove por cento), o que demonstra uma maior concentração entre está faixa etária.

Apesar de $12 \%$ dos entrevistados se encontrarem desempregados, um maior número de pessoas buscou ascender na carreira profissional, consta que 68\% das profissões estão entre advogado, auxiliar administrativo, professor, servidor público entre outros, o que significa um maior número de pessoas com deficiência física com alguma profissão cadastrada na associação, e, portanto está inserido no mercado de trabalho, envolve que estas se percebam como independentes apesar de suas limitações.

No bojo da discussão sobre as ocupações, Figueiredo (2010) verificou na sua pesquisa que as mais realizadas são para quem tem o $3^{\circ}$ grau para funções no setor administrativo e o $2^{\circ}$ grau ou menos é ocupado pela função de serviços gerais.

\begin{tabular}{|c|c|c|c|c|}
\hline \multirow[t]{2}{*}{ PERGUNTAS } & \multicolumn{2}{|c|}{ RESPOSTAS } & \multirow[b]{2}{*}{$\begin{array}{c}\text { Não } \\
\text { Respondeu }\end{array}$} & \multirow[b]{2}{*}{ Total } \\
\hline & SIM & NÃO & & \\
\hline $\begin{array}{l}\text { Em algum momento você se exclui de seu convívio social por } \\
\text { se sentir diferente? }\end{array}$ & $73 \%$ & $22 \%$ & $5 \%$ & $100 \%$ \\
\hline Você se capacitou antes de conseguir o seu primeiro emprego? & $78 \%$ & $20 \%$ & $2 \%$ & $100 \%$ \\
\hline Faz novos cursos para ampliar seu campo de conhecimento? & $76 \%$ & $23 \%$ & $1 \%$ & $100 \%$ \\
\hline $\begin{array}{l}\text { Você já sofreu algum tipo de preconceito ou descriminação em } \\
\text { seu trabalho? }\end{array}$ & $15 \%$ & $80 \%$ & $5 \%$ & $100 \%$ \\
\hline Você gosta da função que exerce em seu trabalho? & $88 \%$ & $5 \%$ & $7 \%$ & $100 \%$ \\
\hline $\begin{array}{l}\text { Você tem uma boa relação profissional com seus colegas de } \\
\text { trabalho? }\end{array}$ & $86 \%$ & $12 \%$ & $2 \%$ & $100 \%$ \\
\hline Dificuldade ao executar as rotinas laborais? & $68 \%$ & $30 \%$ & $2 \%$ & $100 \%$ \\
\hline
\end{tabular}

Quadro 5: Nível de percepções sobre a inclusão no mercado de trabalho 
A pessoa com deficiência física e o mercado de trabalho: estudo empírico no município de Tangará da Serra-MT, dos afiliados da ASTANDEF e empresas inseridas no regime de cotas conforme Lei 8.213/91. Juliano Ribeiro Machado Cleiton Franco

Eder Eugenio Munhão

Sandra Maria de Faria

Dentre o questionário aplicado, procurou-se conhecer a realidade de cada pessoa entrevistada quando se refere ao mercado de trabalho. Na pergunta sobre se sentir excluído 73\% responderam que se sentem excluídos, apesar de todo trabalho para divulgação da inclusão social, percebe-se que ainda há muito a se fazer. Ficou claro a dificuldade dos deficientes físicos de sentirem-se aceitos pela sociedade, por sua vez acabam excluindo-se da mesma para evitar situações constrangedoras. De acordo com a Lei $\mathrm{n}^{\mathbf{0}}$ 7.853/1989, em seu art. $8^{\circ}$, tipificou como crime punível com reclusão de um a quatro anos, e multa:

- II - obstar, sem justa causa, o acesso de alguém a qualquer cargo público, por motivos derivados de sua deficiência;

- II - negar, sem justa causa, a alguém, por motivos derivados de sua deficiência, emprego ou trabalho.

Em relação à capacitação profissional $78 \%$ capacitaram antes de ingressar em seu primeiro emprego, e quando perguntados sobre a pretensão de fazer novos cursos para ampliar seu campo de conhecimento, todos responderam que sim. Ressalta-se que $53 \%$ estão entre o ensino fundamental e médio, e $12 \%$ está desempregado, o que demonstra na parcela dos entrevistados estão se capacitando para ingressar no mercado de trabalho, através dos estudos e capacitação é possível perceber a inclusão.

A questão do preconceito e a discriminação sofrida no trabalho, 15\% transcreveram que sim, isto ainda indica preconceito por parte de alguns empresários. Figueiredo (2010) questiona sobre a trajetória dos entrevistados no mercado de trabalho, em algumas falas os deficientes físicos relataram que ao entrarem para o mercado de trabalho sofreram preconceitos por parte da classe empresarial, que como toda a sociedade desconhecia as informações sobre a PcD. Quanto à função $88 \%$ responderam que gostam da função que exercem e se sentem bem e capazes de exercer a função que são designadas.

Questionou-se também se os mesmos têm uma boa relação profissional com seus colegas de trabalho e $86 \%$ responderam que sim, isso vem demonstrar amadurecimento em relação à forma como se sentem vistas pelos colegas no ambiente de trabalho, isso se deve pelo fato de $80 \%$ ter respondido que não sofreu nenhum preconceito ou descriminação. Os entrevistados responderam ter dificuldade de executar as rotinas laborais, $68 \%$ deles.

\begin{tabular}{|c|c|c|c|c|}
\hline PERGUNTAS & \multicolumn{3}{|c|}{ RESPOSTAS } & \multirow[b]{2}{*}{ Outros } \\
\hline \multirow[b]{2}{*}{$\begin{array}{l}\text { Qual é o seu conhecimento sobre } \\
\text { a "Lei de Cotas" } n^{\circ} 8.213 / 91 ?\end{array}$} & $\begin{array}{c}\text { Não tem } \\
\text { conhecimento }\end{array}$ & Já ouviu falar & Conhece totalmente & \\
\hline & $10 \%$ & $12 \%$ & $78 \%$ & \\
\hline
\end{tabular}


A pessoa com deficiência física e o mercado de trabalho: estudo empírico no município de Tangará da Serra-MT, dos afiliados da ASTANDEF e empresas inseridas no regime de cotas conforme Lei 8.213/91. Juliano Ribeiro Machado

Cleiton Franco

Eder Eugenio Munhão

Sandra Maria de Faria

\begin{tabular}{|l|c|c|c|c|}
\hline \multirow{2}{*}{$\begin{array}{l}\text { Qual a sua avaliação sobre a } \\
\text { acessibilidade nas empresas e } \\
\text { comércios de Tangará da Serra? }\end{array}$} & $3 \%$ & Bom & Ruim & Péssimo \\
\hline $\begin{array}{l}\text { Como você avalia o seu } \\
\text { desempenho na empresa onde } \\
\text { trabalha? }\end{array}$ & $30 \%$ & $5 \%$ & $60 \%$ & $31 \%$ \\
\cline { 2 - 5 } & Excelente & Bom & Razoável & Nenhum \\
\hline $\begin{array}{l}\text { Em sua opinião, quais são as } \\
\text { dificuldades encontradas para } \\
\text { inclusão no mercado de trabalho } \\
\text { de Tangará da Serra-MT? }\end{array}$ & $\begin{array}{c}\text { Falta de cursos } \\
\text { Profissionalizantes }\end{array}$ & $\begin{array}{c}\text { Falta de } \\
\text { acessibilidade }\end{array}$ & $\begin{array}{c}\text { Falta de oferta de } \\
\text { mão-de-obra no } \\
\text { mercado de trabalho }\end{array}$ & Outros \\
\cline { 2 - 5 } & $10 \%$ & $76 \%$ & $17 \%$ & $2 \%$ \\
\hline
\end{tabular}

Quadro 6. Nível de conhecimento sobre a lei 8.213/91.

Com finalidade de concluir a pesquisa, foram elaboradas perguntas, que tentam passar para as PcD pensa e sente em relação ao mercado de trabalho.

No ponto de vista dos entrevistados $78 \%$ conhecem totalmente a lei de cotas, o que corrobora com a informação de $68 \%$ dos entrevistados tem formação profissional e estão inseridos no mercado de trabalho.

Quando se fala de inclusão para a pessoa com deficiência física logo vem à mente a acessibilidade nas empresas. No desenvolver da pesquisa procurou-se saber qual a avaliação sobre a acessibilidade nas empresas e comércios da cidade e $91 \%$ consideram ruim e péssimo, enquanto $68 \%$ tem dificuldade de executar as rotinas laborais demonstrado no quadro 5 . O Decreto 5.296/04 em seu artigo $8^{\circ}$ define a acessibilidade como condição para utilização com segurança e autonomia, total ou assistida, dos espaços, mobiliários e equipamentos urbanos, das edificações, dos serviços de transporte e dos dispositivos, sistemas e meios de comunicação e informação por pessoa com deficiência ou mobilidade reduzida.

As respostas foram bem claras no quesito de desempenho, $81 \%$ consideram excelente e bom, demonstraram firmeza sentem-se bem à vontade na profissão que escolheram, a questão vem a confirmar com $88 \%$ gosta da função que exerce em seu trabalho.

Saber quais as dificuldades encontradas pelas pessoas com deficiência física para sua inclusão no mercado de trabalho é o problema desta pesquisa, como pode se observar no quadro 6, 76\% marcaram na falta de acessibilidade. Para Figueiredo (2010), as empresas precisam eliminar barreiras no ambiente de trabalho, (mobiliário, equipamentos, banheiros, adequar escadas entre outros), a acessibilidade deve ser um dos fatores principais para contratação da pessoa com deficiência, sendo o ponto para um bom desenvolvimento profissional desde colaborador. 
A pessoa com deficiência física e o mercado de trabalho: estudo empírico no município de Tangará da Serra-MT, dos afiliados da ASTANDEF e empresas inseridas no regime de cotas conforme Lei 8.213/91. Juliano Ribeiro Machado Cleiton Franco

Eder Eugenio Munhão

Sandra Maria de Faria

Diante das falas apresentadas pode-se dizer que as respostas parecem sinônimas, a mensagem que os entrevistados gostariam de passar para todas as $\mathrm{PcD}$ que encontram dificuldades de ingressar no mercado de trabalho, é de nunca desistir, lutar sempre, independente de ser deficiente ou não, toda pessoa tem direitos e deveres e precisa participar ativamente de toda as questões da sociedade.

O que mais chamou a atenção na ultima pergunta aberta para as $\mathrm{PcD}$, foi à resposta do presidente da Associação ASTANDEF, senhor Rodrigo Rodrigues, que disse: “Os maiores defeitos das pessoas com deficiência está à vista nos seus corpos físicos e não escondidos no coração, que é isto que a sociedade deve perceber e entender”. E finalizou com a citação de Erving Goffman: "Está, então, implícito, que não é para o diferente que se deve olhar em busca da compreensão da diferença, mas sim para o comum".

\section{CONSIDERAÇÕES FINAIS}

A análise geral dos resultados obtidos na pesquisa induziu a resposta do problema proposto. Diante das respostas dos entrevistados a maior dificuldade encontrada pelas pessoas com deficiência física para sua inclusão no mercado de trabalho é a falta de acessibilidade, o que corrobora com a informação de $91 \%$ consideram ruim e péssimo a acessibilidade nas empresas e comércios de Tangará da Serra.

Vale ressaltar que objetivo desta pesquisa foi alcançado, visto que através dos dados levantados identificou-se que o mercado de trabalho tem dificuldade na contratação de PcD e alegam não encontrar candidatos. Pode ser observado nas informações do IBGE que o referido município tem $20,76 \%$ de $\mathrm{PcD}$, destas, 4.600 apresentam deficiência motora.

Em relação aos objetivos específicos o primeiro foi averiguar se as empresas estão atentas aos procedimentos de contratação exigidos pela lei $n^{\circ}$ 8.213/91 "Lei de Cotas", conforme demonstrado no quadro 2 as empresas estão atentas sobre o que rege a lei em questão. $\mathrm{O}$ segundo e último objetivo especifico, de verificar com as pessoas com deficiência física qual seu conhecimento a respeito da lei de cotas, foi também alcançado, sob a ótica dos entrevistados $78 \%$ conhecem a lei de cotas demonstrado no quadro 6. Os resultados obtidos confirmam o que foi buscado através das entrevistas e questionários, percebeu-se com este estudo, que os deficientes físicos vêm buscando seu espaço na sociedade e no mercado de trabalho, foi possível identificar o perfil dos deficientes físicos, e das empresas que contratam 
A pessoa com deficiência física e o mercado de trabalho: estudo empírico no município de Tangará da Serra-MT, dos afiliados da ASTANDEF e empresas inseridas no regime de cotas conforme Lei 8.213/91. Juliano Ribeiro Machado Cleiton Franco

Eder Eugenio Munhão Sandra Maria de Faria

os mesmos, constatou-se que a inclusão da pessoa com deficiência é a condução para mudança de paradigma e não como formalidade.

Considerando o total de deficientes físicos associados à ASTANDEF, a pesquisa demonstrou um maior número de pessoas buscou ascender na carreira profissional, consta $68 \%$ de profissões está inserido no mercado de trabalho, grande parte deles tem ensino superior, e 78\% procuram fazer novos cursos para ampliar seu campo de conhecimento. Todavia, vale ressaltar que, as empresas e as instituições de ensino também devem praticar a inclusão social, destacando a acessibilidade, estando preparadas para atender as especificidades deste público.

O comportamento inclusivo para Sassaki (2006) é quando uma empresa esta incorporando as seis dimensões sobre acessibilidade tanto nos ambientes internos quanto externos tais como: Dimensão arquitetônica, dimensão comunicacional, dimensão metodológica, dimensão instrumental, dimensão programática e dimensão atitudinal.

As limitações encontradas durante a aplicação do questionário foram muitas, destacando a falta de colaboração por parte de algumas empresas que se recusaram a responder os questionamentos alegando não estarem incluídas na referida lei, bem como que o responsável pelo setor não se encontrava e que teriam que enviar a matriz que esta é em outra cidade. Já com os deficientes físicos a dificuldade encontrada além da falta de uma sede própria para a associação realizar suas reuniões e assembleias observou-se o fato de que a maioria dos associados não tem um meio de locomoção apropriado, bem como o transporte coletivo que atua nesta cidade não está apta a atender esta classe, o que implica na pouca quantidade de frequentadores assíduos durante a reunião em que se deu a aplicação da pesquisa. Sugerem-se outras pesquisas que reavaliem os fatores identificados nos resultados, como por exemplo, porque há dificuldade das empresas em encontrar colaboradores com deficiência física.

Por fim, em menor ou maior percentual, direta ou indiretamente, toda pessoa precisa exercitar a cidadania.

\section{REFERÊNCIAS}

ANDERSON, David R.; SWEENEY, Dennis J.; WILLIAMS, Thomas A. Estatística Aplicada à Administração e Economia. $2^{\circ}$ ed. São Paulo: Pioneira Thomson Learning, 2005. 
A pessoa com deficiência física e o mercado de trabalho: estudo empírico no município de Tangará da Serra-MT, dos afiliados da ASTANDEF e empresas inseridas no regime de cotas conforme Lei 8.213/91. Juliano Ribeiro Machado Cleiton Franco

Eder Eugenio Munhão Sandra Maria de Faria

ALLESIO, Rosimeri. Responsabilidade Social das Empresas no Brasil: Reprodução de Posturas ou Novos Rumos - 2003. Disponível em:

<http://revistaseletronicas.pucrs.br/ojs/índex.php/fass/article/viewFile/952/732>. Acesso em 06 de Agosto 2012.

ASTANDEF. Associação Tangaraense de pessoas com deficiência física. Constituída em 19 de outubro de 2002. Acesso em 13 de Agosto de 2013.

BALDO, Roberta. A Empresa cidadã frente ao Balanço Social. In: Congresso Brasileiro de Ciências da Comunicação, 2002, Salvador. Disponível em:

<http://www.ufjf.br/facom/files/2013/04/TCampos.pdf>. Acesso em 09 de Julho de 2013

BEUREN, Ilse Maria. Como elaborar trabalhos monográficos em Contabilidade: teoria e prática. 3. Ed. São Paulo: Atlas, 2006.

BRASIL. Constituição da Republica Federativa do Brasil. Brasília (DF): Senado, 1988.

BRASIL. Decreto $N^{0}$ 5.296. Regulamenta a Lei $n^{\circ} 10.048$, de 8 de novembro de 2000, que estabelece normas gerais e critérios básicos para promoção da acessibilidade das pessoas com deficiência ou mobilidade reduzida, e dá outras providencias: 02 de dezembro de 2004.

BRASIL. Decreto no ${ }^{\mathbf{~} 3.298}$. Regulamentada pela Lei ${ }^{\circ} 7.853$, de 24 de outubro de 1989 , dispõe sobre a Política Nacional para Integração da Pessoa com Deficiência, consolida as normas de proteção, e dá outras providências. Brasília: 20 de dezembro de 1999.

BRASIL. Lei n. ${ }^{\mathbf{7}}$ 7.853. Dispõe sobre o apoio às pessoas com deficiência, sua integração social, sobre a Coordenadoria Nacional para a Integração da Pessoa com Deficiência (CORDE), institui a tutela jurisdicional de interesse coletivo ou difuso dessas pessoas, disciplina a atuação do Ministério Público, define crimes, e dá outras providências: 24 de outubro de 1989.

BRASIL. Lei $\mathbf{n}^{\circ}$ 8.231 de 24 /07/91. Disponível em:< http://www.saci.org.br>. Acesso em 25 de Julho de 2013.

CARVALHO-FREITAS, M. N. (2007). A inserção de pessoas com deficiência em empresas brasileiras. Tese de doutorado, Universidade Federal de Minas Gerais, Belo Horizonte, Minas Gerais, Brasil. Disponível em:

http://www.scielo.br/scielo.php?script=sci_nlinks\&ref=000201\&pid=S1415-

$6555200900050000900015 \& \operatorname{lng}=$ en. Acesso em 20 de agosto de 2013.

FELIX, Luiz Fernando Fortes. O ciclo virtuoso do desenvolvimento responsável - 2005. Disponível em:

<www.wthos.org.br/_Uniethos/Documents/)\%20Virtuoso\%20do\%20Desenvolvimento\%20R espons\%C3\%A1vel.pdf>. Acesso em 25 de Junho de 2013.

FERREIRA, A. B. H. Novo dicionário da língua portuguesa. 2. ed. Rio de Janeiro: Nova Fronteira, 1986. 
A pessoa com deficiência física e o mercado de trabalho: estudo empírico no município de Tangará da Serra-MT, dos afiliados da ASTANDEF e empresas inseridas no regime de cotas conforme Lei 8.213/91. Juliano Ribeiro Machado Cleiton Franco

Eder Eugenio Munhão Sandra Maria de Faria

FIGUEIREDO, Silvanete. Inclusão da pessoa com deficiência física no mercado de trabalho: Um estudo de caso na Associação baiana de deficientes físicos - ABADEF. Disponível em: <http://www.abadef.com.br>. Acesso em 25 de Julho de 2013.

FONSECA, Ricardo Tadeu Marques da. Proteção Jurídica dos Portadores de Deficiência. Revista de Direitos Difusos n. 4 - São Paulo, IBAP - Instituto Brasileiro de Advocacia Pública \& Editora Esplanada ADCOAS, 2000, p.481/486.

FORD, Henry. Minha Vida, Minha Obra. Rio de Janeiro: Editora Brand, 1954.

GIL, Antônio Carlos. Método e Técnicas de Pesquisa Social. ed. 4, São Paulo - SP: Atlas, p.48, 1995.

INSTITUTO BRASILEIRO DE GEOGRAFIA E ESTATISTICA (IBGE). Censo demográfico. Rio de Janeiro, 2010. Disponível em: www.ibge.gov.br/censo/. Acesso em 11 de fevereiro de 2013.

INSTITUTO ETHOS. O que as empresas podem fazer pela inclusão das pessoas com deficiência. São Paulo: Instituto Ethos, 2002.

LEITE, Anacléia Terezinha. A Inclusão do deficiente auditivo no mercado de trabalho em tangará da Serra-MT, p.12, 2012.

MACIEL, Maria Regina Cazzaniga. Portadores de deficiência a questão da inclusão social. São Paulo Perspec. Vol.14 no. 2 São Paulo Apr./June 2000. Disponível em:

<http://www.scileo.br/scielo.php?pid=s010288392000000200008\&scrip=sci_arttext $>$. Acesso em 19 de Julho de 2013.

LUPPI, Magda Ferreira de Andrade. Inclusão do deficiente intelectual no mercado de trabalho. (Instituto MT de pós-graduação FAC - Faculdade Católica de Cuiabá Programa de pós-graduação em educação especial e inclusão, 2010).

MARTINELLI, Antônio Carlos. Empresa - Cidadã: Uma visão inovadora para uma ação transformadora. In: IOSCHPE, Evelyn Berg (org). $3^{\circ}$ Setor: Desenvolvimento Social sustentado. Rio de Janeiro: Paz e Terra, 1997.

MANTOAN, Maria Tereza Egler. Ser ou estar, eis a questão: explicando o déficit intelectual. Rio de Janeiro: WVA, 2000.

MINISTÉRIO DO TRABALHO E EMPREGO. Anuário Características do Emprego Formal segundo a Relação Anual de Informações Sociais - 2008. Brasília, 2009. Disponível em <http://www.mte.gov.br/rais/2008/arquivos/Resultados_Definitivos.pdf >. Acesso em 24 outubro de 2013.

MOREIRA, Adel de Castro. A inclusão social e popularização da ciência e tecnologia no Brasil. Inclusão Social< Vol. 1, No 2 (2006). Disponível em: 
A pessoa com deficiência física e o mercado de trabalho: estudo empírico no município de Tangará da Serra-MT, dos afiliados da ASTANDEF e empresas inseridas no regime de cotas conforme Lei 8.213/91. Juliano Ribeiro Machado Cleiton Franco

Eder Eugenio Munhão Sandra Maria de Faria

<http://revista.ibict.br/inclusao/index.php/inclusao/article/viewFile/29/51>. Acesso em: 04 de Julho de 2013.

OIT, Organização Internacional do Trabalho. Normas Internacionais do Trabalho sobre Reabilitação Profissional e Emprego de Pessoas com Deficiência. Disponível em: <http://www.oitbrasil.org.br/>. Acesso em 03 de Março de 2013.

OMOTE, S. A Deficiência e a Família. In: MARQUEZINE, M. C., et. al. (Org.). O papel da família junto ao portador de necessidades especiais. Londrina: Eduel, 2003. p.15-18. Disponível em: <http://www.scielo.br/scielo.php?pid=S141365382011000300007\&script=sci_arttext.> Acesso em 25 de Junho de 2013.

ORGANIZAÇÃO DAS NAÇÕES UNIDAS (ONU). Assembleia Geral, 68, 1990, Nova York. Resolução n. 45/91. Brasília: Rede Saci. Disponível em:

<http://www.un.org/disabilities>. Acesso em 11 de fevereiro de 2013.

PASTORE, José. Oportunidades de trabalho para portadores de deficiência. São Paulo: LTR, $2^{\circ}$ ed, 2000.

PASTORE, José. O trabalho dos Portadores de Deficiência - Publicado em O Estado de S. Paulo 02/10/2007. Disponível em:

<www.estadodesaopaulo.br/proj_inter20081/.../cidadania_inclusao_social.pdf>. Acesso em 09 de Julho de 2013.

PEREIRA, José Matias. Manual de Metodologia da Pesquisa Científica. São Paulo: Atlas, 2007.

PRESIDÊNCIA DA REPÚBLICA, Secretária de Direitos Humanos, PORTARIA No 2.344, DE 3 DE NOVEMBRO DE 2010 DOU de 05/11/2010 (nº 212, Seção 1, pág. 4) Resolução $\mathrm{n}^{\mathrm{o}} 1$, de 15 de outubro de 2010, do Conselho Nacional dos Direitos da Pessoa com Deficiência - CONADE, que altera dispositivos da Resolução $n^{\circ} 35$, de 6 de julho de 2005, que dispõe sobre seu Regimento Interno. Disponível em: <www.sistemas.ufrn.br/shared/verArquivo?idArquivo=621492\&key>. Acesso em 05 de novembro de 2013.

PROJETO DE LEI 184/2013 “Empresa Inclusiva” de reconhecimento das iniciativas empresariais que favorecem a integração das pessoas com deficiência em Tangará da Serra. Disponível em: <http://www.camaratga.mt.gov.br/admin/materias/arquivos/sebastiann-071-13.pdf $>$. Acesso em 05 de novembro de 2013.

REIS, Carlos Nelson dos; MEDEIROS, Luis Edgar. Responsabilidade Social das Empresas e Balanço Social: Meios Propulsores de Desenvolvimento Econômico e Social, 1 ed. Editora Atlas. São Paulo, 2009.

RIBEIRO, Maisa de Souza. Contabilidade Social - São Paulo: Saraiva, p. 56, 1992 
A pessoa com deficiência física e o mercado de trabalho: estudo empírico no município de Tangará da Serra-MT, dos afiliados da ASTANDEF e empresas inseridas no regime de cotas conforme Lei 8.213/91. Juliano Ribeiro Machado Cleiton Franco

Eder Eugenio Munhão Sandra Maria de Faria

RIBEIRO, Magno Alves; TORRES, Ariel Lopes; ROCHA, Margarida Alves. Manual para elaboração e apresentação de monografias: com noções introdutórias de metodologia. Tangará da Serra, MT: UNEMAT, 2006.

RODRIGUES, D. A Inclusão na Universidade, (2005): limites e possibilidades da construção de uma universidade inclusiva. Disponível em:

<http://www.conteudoescola.com.br>. Acesso em 04 de Julho de 2013.

RODRIGUES, Elaine; BAGGENSTOSS, Salli; KARLINSKI, Lilian Cristina. Deficiência Intelectual: aceitação de trabalho em Tangará da Serra -MT. 2009.

SASSAKI, Romeu Kazumi. Educação Profissional: desenvolvendo habilidades e competências. In: Ensaios pedagógicos. Brasília: Ministério da Educação, Secretaria de Educação Especial, 2006. Disponível em: $<$ http://www.monografias.com/trabajos27/educacao-inclusiva/educacaoinclusiva.shtml\#ixzz2gnHd9jMl>. Acesso em: 10 de Março de 2013.

SOUZA, E. (2006). Problematizando a equidade: a questão da inclusão profissional da pessoa com deficiência. Dissertação de Mestrado, Departamento de Psicologia Social, Pontifícia Universidade Católica de São Paulo, São Paulo, SP, Brasil.

SENAC DN RIO. Sem limite: Inclusão de pessoas com deficiência no mercado de trabalho. 1 ed. Rio, 2002. Disponível em: <http://www.senac.com.br/10183/17984/000652904.pdf>. Acesso em 09 de Julho 2013.

TACHIZAWA, Takeshy. Gestão ambiental e responsabilidade social corporativa: estratégias de negócios focadas na realidade brasileira. - 2 ed. Revista e ampliada - São Paulo: Atlas, 2004.

TELFORD, W. Charles, SAWER, M James. O individual Excepcional. $4^{\circ}$ ed. Rio de Janeiro, Zahar, 1978.

VERGARA, Sylvia Constant. Projetos e Relatórios de Pesquisa em Administração. - São Paulo - SP: Editora Atlas, 2007. 
A pessoa com deficiência física e o mercado de trabalho: estudo empírico no município de Tangará da Serra-MT, dos afiliados da ASTANDEF e empresas inseridas no regime de cotas conforme Lei 8.213/91. Juliano Ribeiro Machado

Cleiton Franco

Eder Eugenio Munhão

Sandra Maria de Faria 